Scientific paper

\title{
Potentiometric Determination of Phytic Acid and Investigations of Phytate Interactions with Some Metal Ions
}

\author{
Gregor Marolt and Boris Pihlar* \\ Faculty of Chemistry and Chemical Technology, University of Ljubljana, Večna pot 113, SI-1000 Ljubljana, Slovenia \\ * Corresponding author: E-mail: boris.pihlar@fkkt.uni-lj.si \\ Received: 14-10-2014
}

Dedicated to the memory of Prof. Dr. Jurij Brenčič

\begin{abstract}
Determination of correct amount (concentration) of phytic acid is of vital importance when dealing with protonation and/or metal complexation equilibria. A novel approach for precise and reliable assay of phytic acid, based on the difference between end points by potentiometric titration, has been presented. Twelve phytic acid protons are classified into three groups of acidity, which enables detection of 2 to 3 distinct equivalent points (EPs) depending on experimental conditions, e.g. counter-ion concentration. Using the differences between individual EPs enables correct phytate determination as well as identification of potential contamination and/or determination of initial protonation degree. Impact of uncertainty of phytate amount on the calculation of protonation constants has been evaluated using computer simulation program (Hyperquad2013). With the analysis of titration curves different binding sites on phytate ligand have been proposed for complexation of $\mathrm{Ca}^{2+}$ and $\mathrm{Fe}^{3+}$ ions.
\end{abstract}

Keywords: Phytic acid; potentiometric standardization; calcium(II) and iron(III) phytates

\section{Introduction}

Myo-inositol 1,2,3,4,5,6-hexakis(dihydrogen phosphate), known as phytic acid $\left(\mathrm{H}_{12} \mathrm{Phy}\right)$, exhibits six acidic phosphate groups around a cyclohexane ring (Fig. 1). From a chemical point of view it is an unique molecule containing 12 reversibly exchangeable protons and as multidentate ligand shows high ability to form stable coordination compounds with numerous metallic ions. ${ }^{1}$ Inositol phosphates ( $\left.\operatorname{IP}_{x}, 1 \leq x \leq 6\right)$ are naturally occurring compounds synthetized by plants and widely found in natural environment. Many papers deal with antioxidative ${ }^{2-4}$ and anticorrosion ${ }^{5-7}$ properties of phytates and their role in the environment, ${ }^{8}$ biological functions, ${ }^{9}$ human nutrition, ${ }^{10-11}$ and interactions with protons ${ }^{12-14}$ and metallic ions ${ }^{1,15-17}$ in aqueous solutions.

The magnitude of the interaction between metal ions and chelating agents is defined by the corresponding equilibrium constants, and nowadays most of them are determined experimentally by spectrophotometry, potentiometry and other techniques (NMR) in combination with computational analysis of data. ${ }^{18}$ Protonation of phytates and/or determination of stability constants with metallic ions are the subject of numerous publications. ${ }^{1,12,19}$ With help of computerized programs determination of such data becomes easier and published constants are nowadays of high precision, which was not the case by data published in the classical monographs on stability constants, ${ }^{20-21}$ where data frequently scatter between different methods and sources for more orders of magnitude.

The main aim of this work was to check parameters influencing uncertainty of the determination of phytate protonation constants by potentiometric measurements and computerized fitting of titration data. To improve accuracy and reliability of the results involving phytates, a new approach for the alkalimetric standardization of phytic acid was elaborated. It was demonstrated that uncertainty of the ligand concentration participating in the equilibria between phytate and protons/metal ions is one of the most important source of errors by investigation of metal to ligand interactions. 
<smiles>[2H]OP(=O)(O)O[C@H]1[C@@H](OP(=O)(O)O)[C@@H](OP(=O)(O)O)[C@H](OP(=O)(O)O)[C@@H](OP(=O)(O)O)[C@H]1OP(=O)(O)O</smiles>

Figure 1. Structure of phytic acid

\section{Experimental}

\section{1. Materials and Methods}

Stock solution of phytic acid was prepared by weighing the dipotassium salt $\left(\mathrm{K}_{2} \mathrm{H}_{10} \mathrm{Phy}\right.$, Sigma-Aldrich, min. 95\%) and dissolving in ultrapure water with resistivity $>18.2 \mathrm{M} \Omega / \mathrm{cm}$ (Millipore/MilliQ system). Protonated form of phytate was obtained by passing the solution over a strong cationic exchange resin (Dowex 50WX8). Potassium, sodium, calcium and magnesium concentrations in the eluate were analyzed by atomic absorption spectrometer, (Varian AA240), and were all below $3.0 \times 10^{-6} \mathrm{M}$ after single ion exchange procedure. $\mathrm{NaCl}, \mathrm{CaCl}_{2}$ (both Carlo Erba, p. a. grade) and $\mathrm{Fe}\left(\mathrm{NO}_{3}\right)_{3} \cdot 9 \mathrm{H}_{2} \mathrm{O}$ (Merck, p. a. grade) were used without further purification. Iron(III) salt was dissolved in $0.100 \mathrm{M} \mathrm{HNO}_{3}$ to avoid metal hydrolysis and the titration data were corrected for the contribution of $\mathrm{HNO}_{3}$ added into titration cell.

\section{2. Potentiometric Titrations}

Potentiometric titrations were performed at $25 \pm 1{ }^{\circ} \mathrm{C}$ using automatic titrator Metrohm 799 GPT Titrino, equipped with $20 \mathrm{~mL}$ burette (accuracy of the increment $\pm 0.5 \mu \mathrm{L}$ ), carbon dioxide trap, magnetic stirrer (Metrohm) and combined glass electrode (Metrohm 6.0234.100, pH 0-14), which was calibrated at least with two buffer solutions (pH 4.00 and 7.00, Merck) if not stated otherwise. Due to calibration of glass electrode with standard buffers, $\mathrm{pH}$ is given in term of activity (Eq. 2). Titrations were carried out by TiNet 2.4 software (Metrohm). For each titration curve 120-140 data points were collected, and $\mathrm{pH}$ range between 1.5 and 11.0 was used for calculations. Both titrants carbonate-free $0.10 \mathrm{M} \mathrm{NaOH}$ (prepared from concentrated $\mathrm{NaOH}$, Carlo Erba, p. a. grade) and $0.070 \mathrm{M}$ $\mathrm{Bu}_{4} \mathrm{NOH}$ (prepared from $40 \%$ solution, Fluka) were dissolved in ultrapure water deaerated with argon and standardized weekly by potassium hydrogen phthalate pri- mary standard (Merck). For titrations at $1.0 \mathrm{M}$ ionic strength analyte and $\mathrm{NaOH}$ titrant solutions were prepared in $1.0 \mathrm{M} \mathrm{NaCl}$ if not stated otherwise. Initial volume of titration solution was set to $50.0 \mathrm{~mL}$.

\section{3. Calculations}

Equilibrium constants were derived from potentiometric titration data using the Hyperquad2013 software, ${ }^{22}$ and simulated titration curves were produced using the HySS2009 software. ${ }^{23}$

\section{Results and Discussion}

The general protonation equilibrium of phytate $\left(\mathrm{Phy}^{12-}\right)$ can be given by the reaction

$$
\mathrm{H}^{+}+\mathrm{H}_{i-1} \mathrm{Phy}^{(12-i+1)-} \stackrel{K_{i}^{\mathrm{H}}}{\longleftrightarrow} \mathrm{H}_{i} \mathrm{Phy}^{(12-i)-},
$$

where Phy ${ }^{12-}$ represents completely deprotonated form of phytic acid $\mathrm{H}_{12}$ Phy and index $i$ is the number of protonation step, $0 \leq i \leq 12$. At constant ion strength $I$ and temperature $T$ one can define apparent protonation constant $K_{i}^{\mathrm{H}}$, which is given according to the equilibrium (1)

$$
K_{i}^{\mathrm{H}}=\frac{\left[\mathrm{H}_{i} \mathrm{Phy}^{(12-i)-}\right]}{\left[\mathrm{H}^{+}\right]\left[\mathrm{H}_{i-1} \mathrm{Phy}^{(12-i+1)-}\right]},
$$

where $\left[\mathrm{H}^{+}\right]$is given as activity, while other species are given as molar concentrations, therefore constants calculated in this work are mixed (apparent) macroscopic constants. Overall equilibrium constant $\beta_{i}^{\mathrm{H}}$ is defined by equation (3)

$$
i \mathrm{H}^{+}+\mathrm{Phy}^{12-} \stackrel{\beta_{i}^{\mathrm{H}}}{\longleftrightarrow} \mathrm{H}_{i} \mathrm{Phy}^{(12-i)-}, \quad \beta_{i}^{\mathrm{H}}=\Pi K_{i}^{\mathrm{H}}
$$

Titration curve of phytic acid (Fig. 2) shows rather complicated characteristics due to the high number of

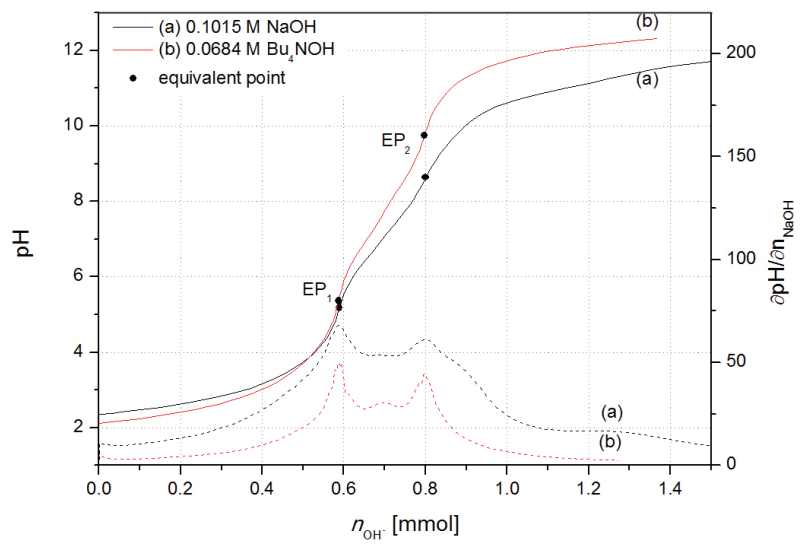

Figure 2. Titration of $0.1061 \mathrm{mmol} \mathrm{H}_{12}$ Phy with (a) $0.1015 \mathrm{M} \mathrm{Na}-$ $\mathrm{OH}$ and (b) $0.0684 \mathrm{M} \mathrm{Bu}_{4} \mathrm{NOH}$. Dashed lines represent the corresponding derivatives $\partial \mathrm{pH} / \partial \mathrm{n}_{\mathrm{OH}^{-}}$. 
(de)protonation steps and relatively small differences between values of protonation constants, $K_{\mathrm{i}}^{\mathrm{H}}$, collected in a review. ${ }^{1}$ The titration of phytic acid proceeds according to the reaction:

$$
\mathrm{H}_{12} \text { Phy }+j \mathrm{OH}^{-} \leftrightarrow \mathrm{H}_{12-j} \mathrm{Phy}^{j-}+j \mathrm{H}_{2} \mathrm{O}
$$

where index $j$ represents the molar ratio between titrant and phytate: $j=n_{\mathrm{OH}} / n_{\mathrm{Phy}}$. From the titration curve it can be seen, that only certain (de)protonation steps are accompanied with a remarkable $\mathrm{pH}$ change during the titration and only two equivalent points (EPs) can be determined successfully from the corresponding derivatives, $\partial \mathrm{pH} / \partial n_{\mathrm{NaOH}}$ of the titration curves. As evident from Fig. 2 titration of phytic acid $\mathrm{H}_{12}$ Phy with $\mathrm{NaOH}$ (curve a) differs from that when $\mathrm{Bu}_{4} \mathrm{NOH}$ titrant was used (curve b). This effect is known well and is due to the complexation of $\mathrm{Na}^{+}$ions with phytate as phytic acid obtains an enhanced acidic character in the presence of alkali ions due to exchange of protons with $\mathrm{Na}^{+}$ions. ${ }^{14,24-26}$ However, in both cases only two EPs $\left(\mathrm{EP}_{1}\right.$ at $\mathrm{pH} 5.3$ and $\mathrm{EP}_{2}$ at $\mathrm{pH}$ 8.5-9.5) can be determined unambiguously. Further from the course of the titration curves is evident that phytic acid contains three categories of protons. In the region before first $\mathrm{EP}_{1}$ a group of strong acidic protons exists with an average dissociation constants $\mathrm{p} K_{\mathrm{a}}$ around $2.6 \pm 0.1$, the second group appears between $\mathrm{EP}_{1}$ and $\mathrm{EP}_{2}$ with an average $\mathrm{p} K_{\mathrm{a}}$ of $7.2 \pm 0.2$, and a third group of protons can be predicted at an average $\mathrm{p} K_{\mathrm{a}}$ of $11.5 \pm 0.5$. Interestingly, these values are very close to that of ortophosphoric acid, ${ }^{14,20}$ but the titration curve of $\mathrm{H}_{3} \mathrm{PO}_{4}$ shown in Fig. 3 (curve b), reveals due to a low number of protons a much sharper $\mathrm{pH}$ transition in the range around both equivalence points, and its content can be determined very accurately by an alkalimetric titration. In the past, assays of phytic acid were based on the precipitation of phytate with iron(III), however, Thompson and Erdman ${ }^{27}$ reported that iron-phosp-

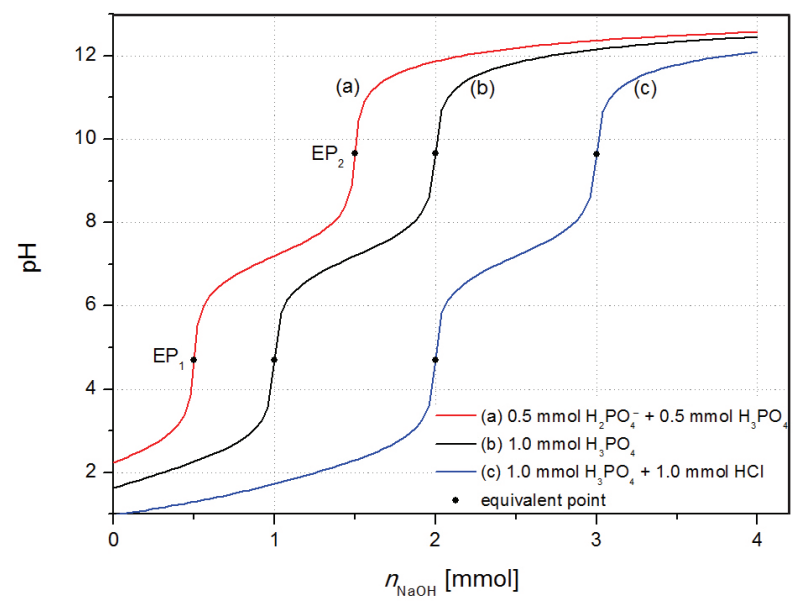

Figure 3. Simulated titration of $10 \mathrm{~mL}$ of a) $0.05 \mathrm{mmol} \mathrm{H}_{3} \mathrm{PO}_{4}+$ $0.05 \mathrm{mmol} \mathrm{H}_{2} \mathrm{PO}_{4}^{-}$, b) $1 \mathrm{mmol} \mathrm{H}_{3} \mathrm{PO}_{4}$, and c) $1 \mathrm{mmol} \mathrm{H}_{3} \mathrm{PO}_{4}+1$ mmol $\mathrm{HCl}$ with $0.20 \mathrm{M} \mathrm{NaOH}$. horus ratio was subject to variation and that assays based on determination of iron from ferric phytate precipitate are not recommended. So titrimetry stays the only promising direct analytical technique, for fast and accurate determination of substances with expressed acidic properties.

From the analytical point of view there appears the question, how to determine an unknown amount of phytic acid on the basis of alkalimetric titration data shown in Fig. 2. We will try to explain this problem on the basis of the above mentioned similarity between phytic and phosphoric acid shown in Figure 3. Such similarity inside of phosphate chemistry is quite common as described a long time ago in a series of papers by Van Wazer et al. ${ }^{28-29}$ It is known that titration of $\mathrm{H}_{3} \mathrm{PO}_{4}$ up to the first $\mathrm{EP}_{1}$ (Fig. 3 , curve b), corresponds to the neutralization of first most acidic proton, and therefore by analogy $\mathrm{EP}_{1}$ of phytic acid should correspond to neutralization of the first group of most acidic protons ( $\mathrm{p}_{\mathrm{a}} 2.6 \pm 0.1$, Fig. 2 ). On the basis of fundamental knowledge of phosphate chemistry, ${ }^{28}$ it can be presumed that phytic acid also contains only one strongly ionized hydrogen for each phosphorous atom, and that six protons are neutralized at $\mathrm{EP}_{1}$. However, due to existence of different isomeric forms of $\mathrm{IP}_{6}$ (e.g. myo, scyllo, neo,... $)^{8,30}$ and $\mathrm{pH}$ dependent conformation change between equatorial (1a5e) and axial (5a1e) orientation of phosphate groups of myo-IP6, ${ }^{12,31}$ deprotonation of $\mathrm{H}_{12}$ Phy is quite more complex process. Brigando et al. ${ }^{12}$ proposed on the basis of ${ }^{31} \mathrm{P}$ NMR titrations that highly acidic protons belong to $\mathrm{P}^{2}, \mathrm{P}^{5}$ and $\mathrm{P}^{1,3}$ phosphate group of $\mathrm{H}_{12}$ Phy. Recently Veiga and coworkers ${ }^{31}$ with the aid of molecular modelling and NMR spectroscopy explain $\mathrm{pH}$ dependent conformational transition and protonation sequence of phytate. These findings may be very helpful for the explanation of intramolecular processes and microequilibria, as well as for the elucidation of the overall deprotonation process of $\mathrm{H}_{12}$ Phy.

While the exact number of protons consumed up to $\mathrm{EP}_{1}$ cannot be determined by alkalimetric titration of an unknown amount of phytic acid, some additional data was required to answer this question.

For a comparison we simulated alkalimetric titration of an equal amounts of phosphate( $(\mathrm{V})$ in the presence of an excess and deficit of protons as shown in Figure 3. Curve (c) shows titration of a mixture of ortophosphoric acid and a strong acid (e.g. $\mathrm{HCl}$ ), and curve (a) represents an equimolar mixture of $\mathrm{H}_{3} \mathrm{PO}_{4}$ and $\mathrm{H}_{2} \mathrm{PO}_{4}^{-}$. In this case the consumption of titrant up to the first $\mathrm{EP}_{1}$ on the curve (c) correspond to the sum of the amounts of $\mathrm{HCl}(1 \mathrm{mmol})$ and $\mathrm{H}_{3} \mathrm{PO}_{4}(1 \mathrm{mmol})$, or in the case of phosphate buffer (curve a), only to the amount of $\mathrm{H}_{3} \mathrm{PO}_{4}(0.5 \mathrm{mmol})$. Therefore, if $\mathrm{H}_{3} \mathrm{PO}_{4}$ or analogously phytic acid is not pure, its amount cannot be determined from the first $\mathrm{EP}_{1}$ only, and for determination of the composition of the mixture, the titration at least to the second $\mathrm{EP}_{2}$ should be performed. For example, by titration of $\mathrm{H}_{3} \mathrm{PO}_{4} / \mathrm{H}_{2} \mathrm{PO}_{4}^{-}$buffer (Fig. 3, cur- 
A)

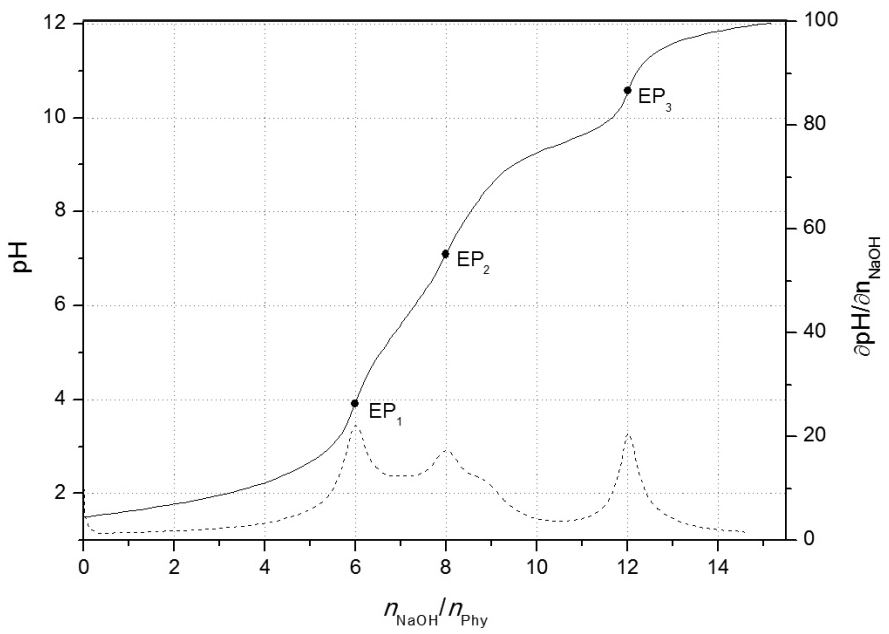

B)

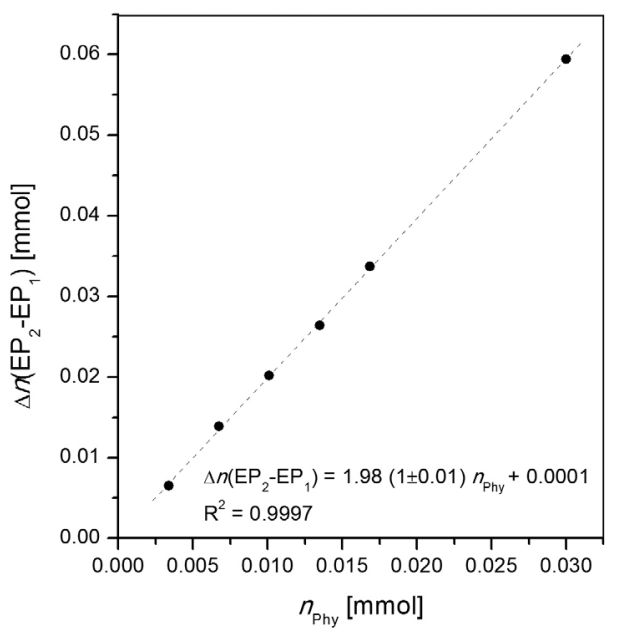

Figure 4. (A) Titration of $0.3081 \mathrm{mmol} \mathrm{H}_{12}$ Phy in $1.0 \mathrm{M} \mathrm{NaCl}$ with $0.0996 \mathrm{M} \mathrm{NaOH}$. Equivalents of $\mathrm{NaOH}$ per mole of phytate are given on $\mathrm{x}$-axis. Dashed line represents the corresponding derivative $\partial \mathrm{pH} / \partial \mathrm{n}_{\mathrm{NaOH}}$ (B) Linear dependence of $\Delta n\left(\mathrm{EP}_{2}-\mathrm{EP}_{1}\right)$ versus $n_{\mathrm{Phy}}$ added into titration cell.

ve a), the difference between $\mathrm{EP}_{2}$ and $\mathrm{EP}_{1}$ gives the total amount of phosphates as by the titration of pure $\mathrm{H}_{3} \mathrm{PO}_{4}$ (curve $\mathrm{b}$ ), and $\mathrm{EP}_{1}$ then equals to the concentration of $\mathrm{H}_{3} \mathrm{PO}_{4}$ originally present in the buffer. Also a mixture of $\mathrm{H}_{3} \mathrm{PO}_{4}$ and $\mathrm{HCl}$ (curve c) can be analyzed on this basis since difference $\mathrm{EP}_{2}-\mathrm{EP}_{1}$ equals to the amount of phosphoric acid and $\mathrm{EP}_{1}$ represent the sum of the amounts of $\mathrm{HCl}$ and $\mathrm{H}_{3} \mathrm{PO}_{4}$.

By analogy, difference between $\mathrm{EP}_{2}$ and $\mathrm{EP}_{1}$ by alkalimetric titration of phytates should give the unknown amount of the analyte. However, again the equivalent amount of protons consumed between $\mathrm{EP}_{2}$ and $\mathrm{EP}_{1}$ remains unknown. The solution of this complex task was found in the interaction between phytate and metallic ions and formation of a relatively strong complexes of the alkaline cations with phytates. ${ }^{14,24-26}$ As mentioned above sodium ions significantly increase acidity of phytate due to complexation (Fig. 2, curve a), but at this low concentration of titrant (low ionic strength, $I$ ), complete deprotonation to its final $12^{\text {th }}$ step does not occur. This step can be detected just by very low maximum on the derivative curve at approx. 1.25 mmols of added $\mathrm{NaOH}$. This is in accordance with relatively high $K_{i}^{\mathrm{H}}$ values of phytate at low ionic strength for $i \leq 3 .{ }^{32}$ To stimulate deprotonation of phytic acid therefore the exchange with sodium or other alkaline ions should be exploited. ${ }^{14,24}$

In Fig. 4A alkalimetric titration of phytic acid in the presence of $1 \mathrm{M} \mathrm{NaCl}$ is shown. From the curve is evident, that high concentration of $\mathrm{Na}^{+}$ions enhanced substantially the acidity of the last group of protons still bonded to the phytate ligand at $\mathrm{pH}$ above 8 . As a consequence of the formation of a stable Na-Phy complexes $\left(\log K_{1}^{\mathrm{H}}=8.69\right)^{25}$, a third well shaped equivalence point $\mathrm{EP}_{3}$ on the titration curve appears at $\mathrm{pH} 10.6$ indicating the final $\left(12^{\text {th }}\right)$ deprotonation step of phytate. Appearance of this third $\mathrm{EP}_{3}$ finally clarifies the pathway of the titration route of phytic acid by standardized solution of $\mathrm{NaOH}$. Using the known amount of phytate $\left(n_{\text {Phy }}\right)$ and adjustment of moles of $\mathrm{NaOH}$ to equivalents per mole of phytate $j\left(n_{\mathrm{OH}} / n_{\mathrm{Phy}}\right)$, one can deduce that the $\mathrm{EP}_{1}, \mathrm{EP}_{2}$ and $\mathrm{EP}_{3}$ correspond to $6^{\text {th }}, 8^{\text {th }}$ and $12^{\text {th }}$ deprotonation step, respectively according to the reactions:

$$
\begin{array}{ll}
\mathrm{EP}_{1} & \mathrm{H}_{12} \mathrm{Phy}+6 \mathrm{OH}^{-} \leftrightarrow \mathrm{H}_{6} \mathrm{Phy}^{6-}+6 \mathrm{H}_{2} \mathrm{O} \\
\mathrm{EP}_{2} & \mathrm{H}_{6} \mathrm{Phy}^{6-}+2 \mathrm{OH}^{-} \leftrightarrow \mathrm{H}_{4} \mathrm{Phy}^{8-}+2 \mathrm{H}_{2} \mathrm{O} \\
\mathrm{EP}_{3} & \mathrm{H}_{4} \mathrm{Phy}^{8-}+4 \mathrm{OH}^{-} \leftrightarrow \mathrm{Phy}^{12-}+4 \mathrm{H}_{2} \mathrm{O}
\end{array}
$$

Due to a strong affinity of Phy to sodium ions, the above mentioned species at high $I$ and excess of $\mathrm{Na}^{+}$ions do not exist in its written forms in reality. For example $\mathrm{H}_{4} \mathrm{Phy}^{8-}$ and Phy ${ }^{12-}$ most probably exists in forms of $\mathrm{Na}_{3} \mathrm{H}_{4} \mathrm{Phy}^{5-}$ and $\mathrm{Na}_{6} \mathrm{Phy}^{6-}$ species, respectively. ${ }^{14,19}$

To our knowledge only Bieth and Spiess ${ }^{13}$ reported standardization of the amount (concentration) of phytate with the differential technique. They used the difference between two inflection points corresponding to the neutralization of 6 protons of phytic acid at molar concentration of $\mathrm{NaClO}_{4}$. Although not explained into the details, they probably took into account the final deprotonation step ( $\mathrm{EP}_{3}$ in Fig. 4), which required an addition of an excess of alkali metal $(\geq 1.0 \mathrm{M})$ into titration solution. Whilst other of numerous research groups dealing with the protonation and/or metal complexation equilibria of phytates ${ }^{1524-25,33-34}$ reported on an "alkalimetric/acidimetric" standardization of the ligand concentrations, or by elemental analysis ${ }^{35}$ or simply used commercialy supplied chemicals without any proof of its purity.

Since the accuracy of a titrimetric standardization procedure is of vital importance for interaction and complexation studies of phytates with metallic ions, any un- 
certainties in the determination of EPs should be minimized and every systematic error in the evaluation procedures of the analyte determination should be avoided. On the basis of titration shown in Fig. 4A, reactions (5) to (7), and discussion and explanations stated above, the differential approach should be used for an accurate and reliable determination of an unknown amount of phytate. Although first and third EPs shows much better transition than $\mathrm{EP}_{2}$ (Fig. 4A), we found that the difference between $\mathrm{EP}_{2}$ and $\mathrm{EP}_{1}$ remains constant also in the presence of alkaline metallic ions, and by variation of phytate concentrations. Linear dependence between the amount of $\mathrm{OH}^{-}$consumed between $\mathrm{EP}_{1}$ and $\mathrm{EP}_{2}\left(\Delta n\left(\mathrm{EP}_{2}-\mathrm{EP}_{1}\right)\right)$ and $n_{\text {Phy }}$ is shown in Figure 4B with the slope value of $1.98 \pm 0.02$ $\left(R^{2}=0.9997\right)$. On the basis of this data one can again confirm, that 2 moles of $\mathrm{OH}^{-}$per 1 mole of phytate are consumed between $\mathrm{EP}_{1}$ and $\mathrm{EP}_{2}$ according to the relationship:

$$
\Delta n\left(\mathrm{EP}_{2}-\mathrm{EP}_{1}\right)=2 n_{\text {Phy }}
$$

This relation enables a precise $\left(s_{\text {rel. }}<1 \%, N=5, n_{\text {Phy }}\right.$ $=7.18 \mu \mathrm{mol})$ and reliable determination of low amounts of phytate, particularly in cases with difficulties with final $\mathrm{EP}_{3}$ detection. For instance, titration in the electrolyte with low ionic strength (Fig 2, curve a) and/or titration with a bulky counter cation titrants, e.g. $\mathrm{Bu}_{4} \mathrm{NOH}$ (Fig. 2, curve $b$ ), or the presence of other multivalent cations (see below).

On the basis of equation (8) an excess of a strong acid (e.g. $\mathrm{HNO}_{3}$ ) added to the phytic acid solution is easily detected by an equivalent shift of $\mathrm{EP}_{1}$ to higher values, but difference between $\mathrm{EP}_{2}$ and $\mathrm{EP}_{1}$ remains constant and is twice the amount of phytic acid in a mixture. Also a mixture of an equivalent amounts of $\mathrm{H}_{12}$ Phy and $\mathrm{K}_{2} \mathrm{H}_{10}$ Phy can be analyzed, where first $\mathrm{EP}_{1}$ reflects the sum of the amounts of six and four of the most acidic protons of $\mathrm{H}_{12}$ Phy and $\mathrm{K}_{2} \mathrm{H}_{10}$ Phy according to the reaction (5), respectively, and the difference $\mathrm{EP}_{2}-\mathrm{EP}_{1}$ then corresponds according to the reaction (6) to the transition of $\mathrm{H}_{6}$ Phy to $\mathrm{H}_{4}$ Phy of both phytate salts and is thus proportional to the total amount of phytates present in the mixture.

It is important to note that any significant deviation from above mentioned course of the titration (e.g. shift of EPs) indicate that analyzed phytic acid $\mathrm{H}_{12}$ Phy is not pure, and may contain moisture, other phytate salts or impurities, and/or multivalent metallic cations. Declared purity of commercially available phytic acid and its salts $\left(\mathrm{K}_{2} \mathrm{H}_{10} \mathrm{Phy}, \mathrm{Na}_{6} \mathrm{H}_{6} \mathrm{Phy}, \mathrm{Na}_{12} \mathrm{Phy}\right)$ is less than $95 \%$. Due to natural origin of $\mathrm{IP}_{6}$ and its hydrolysis it may contain lower inositol phosphates $\left(\mathrm{IP}_{2}-\mathrm{IP}_{5}\right)$, which can affect the shape of the titration curve. As shown by Persson et al. ${ }^{36}$ alkalimetric titration of $\mathrm{IP}_{3}, \mathrm{IP}_{4}, \mathrm{IP}_{5}$, and $\mathrm{IP}_{6}$ results in an appropriate shift of the first EP. Therefore if sample contains lower IPs a separation before the titration is required. Such impurities can be identified using HPLC ${ }^{37}$ or ion chromatography. ${ }^{38}$

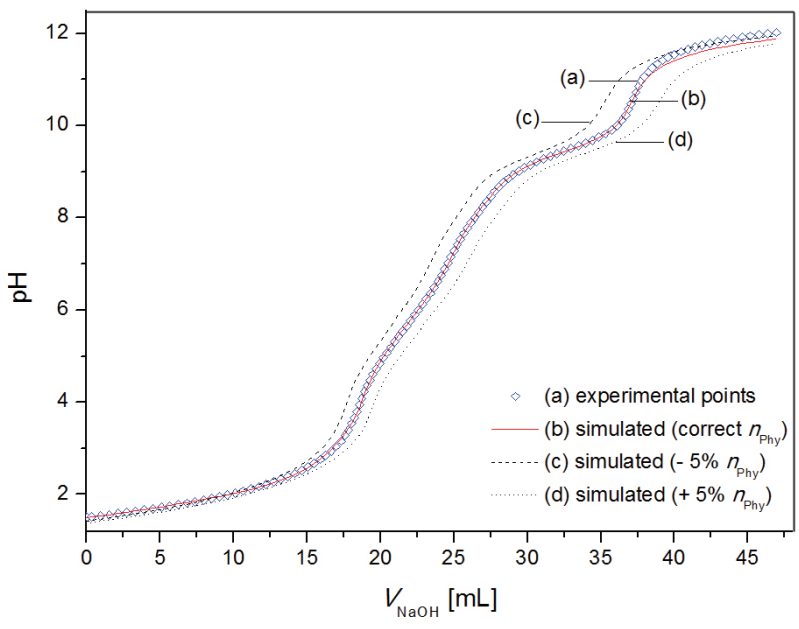

Figure 5. Titration of $0.3081 \mathrm{mmol} \mathrm{H}_{12}$ Phy with $0.0996 \mathrm{M} \mathrm{NaOH}$ in $1.0 \mathrm{M} \mathrm{NaCl}$. (a) Squares represent observed experimental points and lines represent simulated curves using (b) correct amount of phytate, (c) $-5 \%$ and (d) $+5 \%$ deviation in amount of total phytate. Protonation constants used for simulations (c) and (d) were same as calculated for the correct amount of phytate (curve b). Initial molar ratio between protons and phytate was set to 12.0 in all cases.

The importance of an accurate standardization of phytate ligands used in the complexation studies can be seen from the Figure 5 and Table 1, where an experimental titration curve was fitted by a computer. As shown, a relatively small error in phytate amount generates large differences in calculated protonation constants. Figure 5 curve (a), shows experimental points (labeled as squares) obtained by potentiometric titration of pure phytic acid $\mathrm{H}_{12}$ Phy with $\mathrm{NaOH}$ in the presence of $1.0 \mathrm{M} \mathrm{NaCl}$. Apparent macroscopic protonation constants of phytate were then calculated (Table 1) by fitting the potentiometric data (curve b) using the Hyperquad2013 program. If the titration curve were simulated by the same calculated constants and with 5\% lower (curve c) and 5\% higher amounts of phytate (curve d), a significant deviation from the experimental titration curve is observed (Fig. 5). Results listed in Tabele 1 reveal considerable differences between $K_{i}^{\mathrm{H}}$ values calculated when a small deviations from correct $n_{\text {Phy }}$ are applied to simulation program. For instance, at fourth protonation step $(i=4)$ values of 7.25, 7.95 and 8.60 were obtained for $\log K_{i}^{\mathrm{H}}$ at $-5 \%, 0 \%$ and $+5 \%$ deviation of $n_{\text {Phy }}$ from the experimental true value, respectively.

Differences between logarithm values can be converted to factors of 5.04 and 4.47 on the linear scale, while already a 35 -fold higher $K_{4}^{\mathrm{H}}$ was calculated when $+10 \%$ error in $n_{\text {Phy }}$ was applied to the refinement process. Evidently, a brief attention should be given to accurate phytate determination, particularly when dealing with protonation and/or complexation equilibria as stated also by Brigando et al. ${ }^{12}$ Moreover, precision of the reported protonation and stability constants in the literature without a care- 
Table 1. Apparent protonation constants with calculated standard deviations of phytate in $1.0 \mathrm{M} \mathrm{NaCl}$ at $T=298 \mathrm{~K}$, calculated from experimental data shown in Fig. 5 (a) using different deviations from the actual amount of phytate present in titration cell and comparison with literature.

\begin{tabular}{lcccc}
\hline Error of $\boldsymbol{n}_{\text {Phy }}$ & $\mathbf{- 5 \%}$ & $\mathbf{0 \%}^{\mathbf{b}}$ & $\mathbf{+ 5 \%}$ & $\mathbf{+ 1 0 \%}$ \\
\hline $\log K_{1}^{\mathrm{Ha}}$ & $9 \pm 1$ & $9.6 \pm 0.2$ & $11.0 \pm 0.7$ & $15 \pm 1$ \\
$\log \mathrm{K}_{2}^{\mathrm{H}}$ & $9.7 \pm 0.9$ & $9.3 \pm 0.2$ & $8.6 \pm 0.7$ & $10 \pm 1$ \\
$\log \mathrm{K}_{3}^{\mathrm{H}}$ & $8.6 \pm 0.1$ & $9.4 \pm 0.1$ & $10.2 \pm 0.1$ & $9.9 \pm 0.3$ \\
$\log \mathrm{K}_{4}^{\mathrm{H}}$ & $7.25 \pm 0.07$ & $7.95 \pm 0.03$ & $8.60 \pm 0.08$ & $9.5 \pm 0.1$ \\
$\log \mathrm{K}_{5}^{\mathrm{H}}$ & $5.79 \pm 0.09$ & $6.23 \pm 0.03$ & $6.89 \pm 0.05$ & $7.50 \pm 0.09$ \\
$\log \mathrm{K}_{6}^{\mathrm{H}}$ & $4.35 \pm 0.07$ & $4.96 \pm 0.03$ & $5.44 \pm 0.05$ & $5.82 \pm 0.8$ \\
$\log \mathrm{K}_{7}^{\mathrm{H}}$ & $1.92 \pm 0.06$ & $2.73 \pm 0.07$ & $3.48 \pm 0.06$ & $4.06 \pm 0.08$ \\
$\log \mathrm{K}_{8}^{\mathrm{H}}$ & $1.93 \pm 0.09$ & $1.92 \pm 0.06$ & $1.75 \pm 0.08$ & $2.1 \pm 0.1$ \\
$\log \mathrm{K}_{9}^{\mathrm{H}}$ & $<1.5^{\mathrm{c}}$ & $<1.5$ & $<1.5$ & $<1.5$ \\
$\log \mathrm{K}_{10}^{\mathrm{H}}$ & $<1.5$ & $<1.5$ & $<1.5$ & $<1.5$ \\
$\log \mathrm{K}_{11}^{\mathrm{H}}$ & $<1.5$ & $<1.5$ & $<1.5$ & $<1.5$ \\
$\log \mathrm{K}_{12}^{\mathrm{H}}$ & $<1.5$ & $<1.5$ & $<1.5$ & $<1.5$ \\
\hline
\end{tabular}

${ }^{\mathrm{a}} K_{\mathrm{i}}^{\mathrm{H}}$ refers to the equilibrium reaction (1). ${ }^{\mathrm{b}}$ Values calculated from titration curve (a). ${ }^{\mathrm{c}}$ Estimated values are given in italics.

ful standardization of the ligand, should be addressed with precaution despite being determined with highly powerful computation programs and measured at well-established experimental conditions, e.g. temperature, ionic strengths, calibration of burettes and electrodes etc.

From the protonation constants given in Table 1 we can also see, that phytic acid actually contains three different categories of protons as presumed above. A first group of six the most acidic protons have log protonation constants less than $2.7\left(\log K_{12}^{\mathrm{H}}\right.$ to $\left.\log K_{7}^{\mathrm{H}}\right)$ two protons of an intermediate acidity with protonation constants $\log K_{6}^{\mathrm{H}}$ $=4.96$ and $\log K_{5}^{\mathrm{H}}=6.23$, and the last group of four most strongly bonded protons have the log protonation constants between $7.95\left(\log K_{4}^{\mathrm{H}}\right)$ and $9.6\left(\log K_{1}^{\mathrm{H}}\right)$. Such differences in the acidity is a consequence of strong intramolecular hydrogen bonding between phosphate groups and $\mathrm{pH}$ dependent stabilization of two conformations. ${ }^{12}$

As we mentioned above, presence of the multivalent cations affect the shape of the titration curve of phytate with $\mathrm{NaOH}$ as shown on Fig. 6. It can be seen that addition of $\mathrm{Ca}^{2+}$ to phytic acid due to complexation and consequent substitution of protons increased its acidity in region between $\mathrm{EP}_{1}$ and $\mathrm{EP}_{2}$. Three EPs were detected from titration curve of phytic acid in the presence of various amounts of calcium (Fig. 6A). If molar ratio between $\mathrm{M}^{\mathrm{z+}}$ $\left(\mathrm{Ca}^{2+}\right.$ in this case) and phytate $m=n_{\mathrm{M}} / n_{\text {Phy }}$ is increased from 0:1 (curve a) to 1:1 (curve b) and 2:1 (curve c), a significant shift of $\mathrm{EP}_{2}$ is observed, while $\mathrm{EP}_{1}$ and $\mathrm{EP}_{3}$ remain constant. Also the course of the titration curve before the first and after the last equivalent point stays the same as in the absence of the metal. This indicate that equation (8) will not give the correct amount of phytate when solution contains $\mathrm{Ca}^{2+}$ (or other alkaline earth cations) as an impurities. In this case for titrimetric determination of phytic acid the difference between $\mathrm{EP}_{3}$ and $\mathrm{EP}_{1}$ should be used according to reactions (5) to (7):

$$
\Delta n\left(\mathrm{EP}_{3}-\mathrm{EP}_{1}\right)=6 n_{\text {Phy }} .
$$

Figure 6B shows dependence of $\mathrm{NaOH}$ equivalents (j) consumed at different EPs on the equivalents of calcium $(m)$ added into solution. A linear relation with a slope value of +0.59 is obtained for $\mathrm{EP}_{2}$, indicating that over a half of mole of protons was released from phytate per one mole of added calcium around $\mathrm{pH}$ 7.5. Calcium ions like alkaline ions evidently compete for binding sites on phosphate group(s) with $\mathrm{H}^{+}$ions of low acidity. The latter is, however, not the case for the group of six most acidic protons, which are not subjected to the influence of calcium, as the titration curve remains unchanged up to the $\mathrm{EP}_{1}$, where the $6^{\text {th }}$ equivalent of $\mathrm{H}^{+}$is neutralized, as also reported by Martin and Evans ${ }^{16}$ and Veiga et al. ${ }^{31}$ After the final deprotonation step $\left(\mathrm{EP}_{3}\right)$ both titration curves recorded in the presence of $\mathrm{Ca}^{2+}$ (curves b, c) follow the same shape as the one obtained in the absence of $\mathrm{Ca}^{2+}$ and the amount of $\mathrm{NaOH}$ consumed to neutralize the $12^{\text {th }}$ proton remains practically unchanged (slope value of $\mathrm{EP}_{3}<$ -0.03 , Fig. 6B). Similarly as in the case of $\mathrm{Na}^{+}$(Fig. 4A) an evident increase of derivative peak $\partial \mathrm{pH} / \partial n_{\mathrm{OH}^{-}}$is observed at $\mathrm{EP}_{3}$ when $\mathrm{Ca}^{2+}$ is present in solution, indicating a decrease of apparent protonation constants of phytate at low protonation degree $(i \leq 4)$ due to formation of stable coordination compounds. ${ }^{17}$ Since $\mathrm{EP}_{1}$ and $\mathrm{EP}_{3}$ retain their respective positions upon addition of $\mathrm{Ca}^{2+}$, the above described shift of $\mathrm{EP}_{2}$ could be used as direct indication of contamination of phytic acid with divalent cation, e.g. $\mathrm{Ca}^{2+}$ or $\mathrm{Mg}^{2+}$, which is often the case for naturally occurring phytate salts. ${ }^{39}$

Phytates interact strongly also with iron(III) ions and play an important role in biologically-relevant processes as described in numerous papers. ${ }^{8,35,40-44}$ Complexation of iron(III) ions with phytate show different behavior than alkaline or alkaline earth cations. Three distinct EPs are detected on titration curves of phytic acid in the presence of various amounts of $\mathrm{Fe}^{3+}$ ions (Fig. 7A) and a shift of all three EPs is observed upon addition of $\mathrm{Fe}^{3+}$. Presence of $\mathrm{Fe}^{3+}$ causes two additional complications as iron(III) 
A)

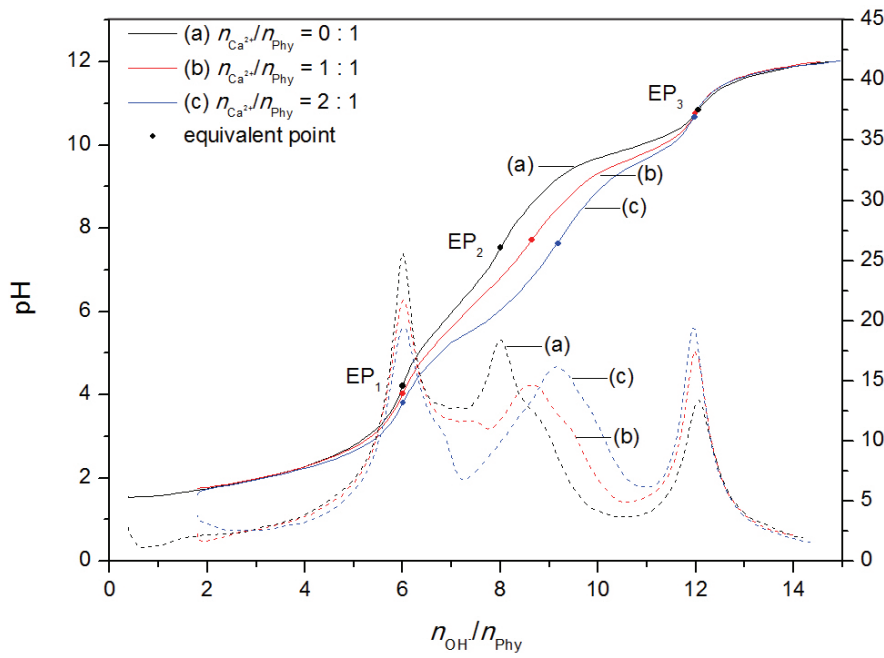

B)

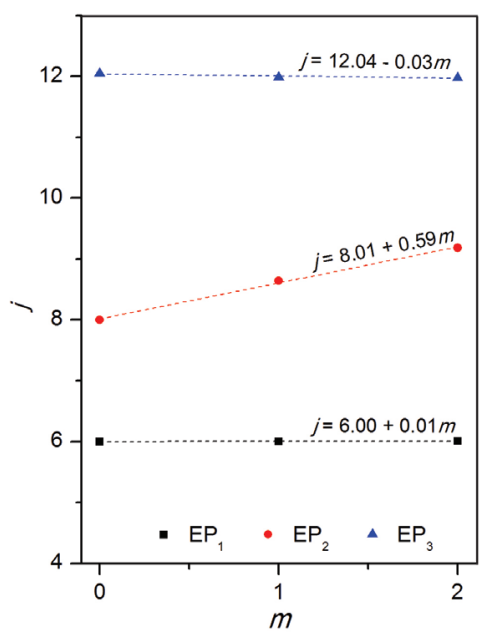

Figure 6. (A) Titration of $0.3104 \mathrm{mmol} \mathrm{H}_{12} \mathrm{Phy}$ (in the presence of $0.25 \mathrm{M} \mathrm{NaCl}$ ) with $0.1032 \mathrm{M} \mathrm{NaOH}$ at various molar ratios $n_{\mathrm{Ca}} / n_{\mathrm{Phy}}$ : (a) $0: 1$, (b) $1: 1$, and (c) 2:1, accompanied with corresponding derivatives $\partial \mathrm{pH} / \partial \mathrm{n}_{\mathrm{OH}^{-}}$. (B) Equivalents of $\mathrm{OH}^{-}$per amount of phytate consumed at equivalent points from part A.

undergoes hydrolysis ${ }^{35,45}$ and at $\mathrm{pH}$ above 9.5 precipitation of brown iron(III) hydroxides despite the presence of strong phytate ligand..$^{35,44-45}$ As reported by Šala et. al. ${ }^{43}$ and Mali et. $a l^{46}$ a white-colored iron(III)-phytate precipitate is formed in acidic solution at molar ratios $m$ $\left(n_{\mathrm{Fe}} / n_{\mathrm{Phy}}\right)$ above 0.25 . Due to the latter, EPs recorded for $m$ $>0.25$ (shown as grey marks in Figure 7B) were excluded from further calculations, hereinafter. Linear dependence of $\mathrm{NaOH}$ equivalents $(j)$ consumed at each EPs on the molar ratio $m$ (Fig. 7B) gives slope values of 1.67, 2.26, and 1.94 for $\mathrm{EP}_{1}, \mathrm{EP}_{2}$ and $\mathrm{EP}_{3}$, respectively. Shift of $\mathrm{EP}_{1}$ indicates that over 1.5 mole of $\mathrm{H}^{+}$is released per 1 mole of $\mathrm{Fe}^{3+}$ bound to phytate, which is close to results reported in the literature. ${ }^{43} \mathrm{Fe}^{3+}$ apparently competes with $\mathrm{H}^{+}$ions for binding sites on phytate and enhanced acidity of protons with intermediate character. The released protons behave as a strong acid and are neutralized earlier, i.e. before $\mathrm{EP}_{1}$ and the solution show properties of a mixture of strong and weak acids like in Fig. 3c. This is different than in the presence of $\mathrm{Ca}^{2+}$ (Fig. 6B), where only $\mathrm{EP}_{2}$ was shifted upon addition of the metal, and is a clear indication of different binding sites for $\mathrm{Fe}^{3+}$ and $\mathrm{Ca}^{2+}$ on phytate ligand.

Greater shift of $\mathrm{EP}_{2}$ (slope value of 2.26, Fig. 7B) can be again explained with pronounced acidity of certain protons and/or with more intensive $\mathrm{Fe}^{3+}$ hydrolysis side reaction, which requires additional consumption of $\mathrm{NaOH}$. The final equivalent point $\left(\mathrm{EP}_{3}\right)$ corresponds to the neutralization of 12 protons and the consumption of $\mathrm{NaOH}$ at the $\mathrm{EP}_{3}$ is increased for +1.94 mole per 1 mole of $\mathrm{Fe}^{3+}$. This is a clear evidence of parallel metal hydrolysis, also visibly observed as brownish precipitate formed during the titration at $\mathrm{pH}$ above 9.5. Taking into account
A)

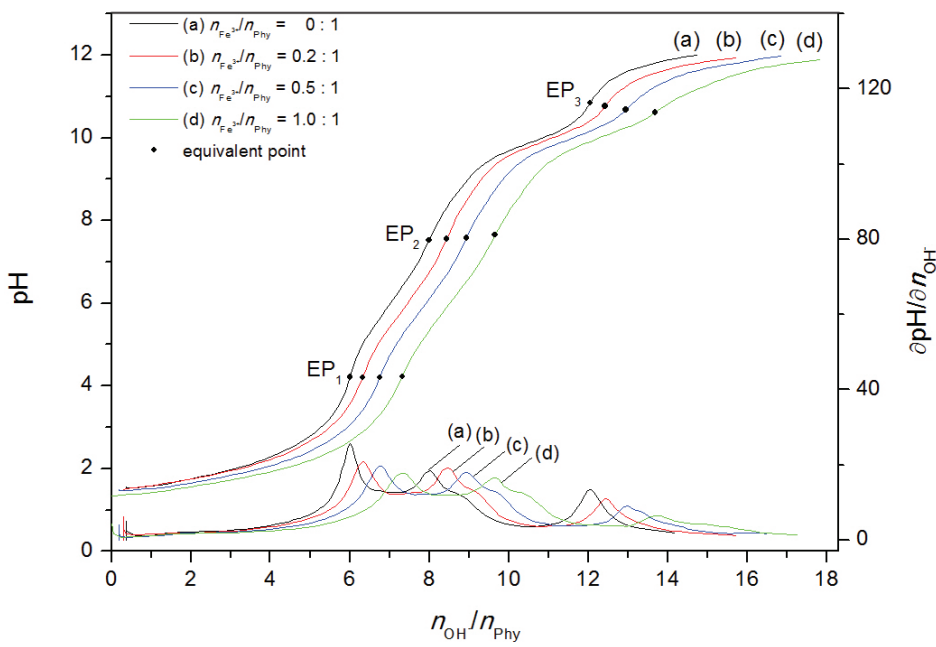

B)

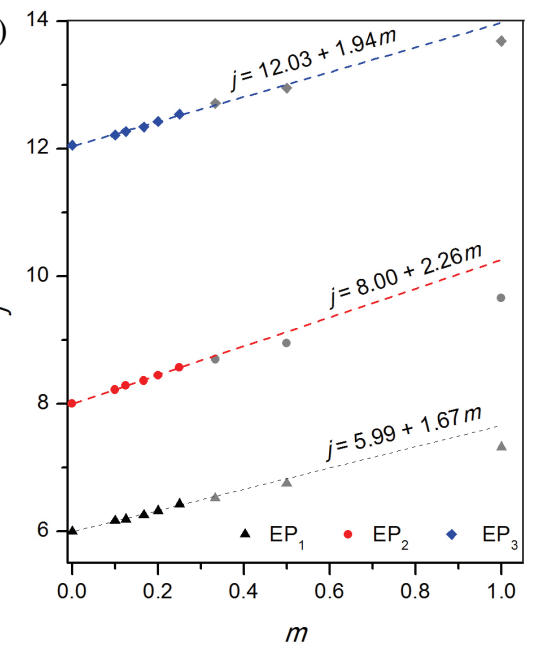

Figure 7. (A) Titration of $0.3104 \mathrm{mmol} \mathrm{H}_{12} \mathrm{Phy}$ (in the presence of $0.25 \mathrm{M} \mathrm{NaCl}$ ) with $0.1008 \mathrm{M} \mathrm{NaOH}$ at various molar ratios $n_{\mathrm{Fe}} / n_{\mathrm{Phy}}$ (a) $0: 1$, (b) $0.2: 1$, (c) $0.5: 1$, and (d) $1: 1$, accompanied with corresponding derivatives $\partial \mathrm{pH} / \partial \mathrm{n}_{\mathrm{OH}^{-}}$. (B) Equivalents of $\mathrm{OH}^{-}$per amount of phytate $(j)$ versus molar ratios $m\left(m=n_{\mathrm{Fe}} / n_{\text {Phy }}\right)$ consumed at different EPs from part A. 
theoretical (3 moles) and actual (1.94 mole) consumption of $\mathrm{NaOH}$ per 1 mole of added $\mathrm{Fe}^{3+}$ one can calculate that around $35 \%$ of $\mathrm{Fe}^{3+}$ is still present as soluble phytate complex at $\mathrm{EP}_{3}$ despite relatively high $\mathrm{pH}(>10.6)$. This is in accordance with high stability constants of iron(III)phytate complexes reported in the literature. ${ }^{35}$

From the analytical point of view, contamination of phytic acid with $\mathrm{Fe}^{3+}$ can be distinguished from the one with $\mathrm{Ca}^{2+}$, as the consumption of $\mathrm{NaOH}$ at each equivalent point, namely $\mathrm{EP}_{1}, \mathrm{EP}_{2}$ and $\mathrm{EP}_{3}$ differs from theoretical 6 , 8 and 12 equivalents, respectively. However, due to accompanying competitive reactions (metal hydrolysis, complexation, and complex precipitation), titrimetric standardization of phytic acid in the presence of $\mathrm{Fe}^{3+}$ is a challenging task, as neither of equations (8) and (9) can be applied. Therefore $\mathrm{Fe}^{3+}$ removal prior to performing titrimetric analysis is required.

\section{Conclusions}

The main aim of the present work was to evaluate phytic acid/phytate standardization with potentiometric titrations. Correct determination of phytate is of vital importance, as relatively small errors in determination of total phytate amount generate large differences in protonation constants calculated using computer simulation programs. A novel differential titration method was elaborated on the basis of equivalent point difference $\left(\mathrm{EP}_{2}-\mathrm{EP}_{1}\right.$ and/or $\mathrm{EP}_{3}-\mathrm{EP}_{1}$ ) calculation. Presented method enables precise and reliable determination of low amounts of phytic acid down to $\mu$ mol levels, particularly in the case of electrolytes with low ionic strength and/or when bulky counter cation titrants (e.g. $\left.\mathrm{Bu}_{4} \mathrm{NOH}\right)$ are used for potentiometric titrations. Moreover, contamination of phytic acid with multivalent cations, such as $\mathrm{Ca}^{2+}$ and $\mathrm{Fe}^{3+}$, can be detected distinguishably, and in the case of alkaline earth ions correct determination of phytate is available as well. Different binding sites on phytate ligand were predicted for $\mathrm{Ca}^{2+}$ and $\mathrm{Fe}^{3+}$ complexation using the analysis of titration curves of phytic acid recorded in the absence and presence of both compared metals.

\section{Acknowledgement}

This work was supported by Slovenian Research Agency (grant No. P1-0153).

\section{References}

1. F. Crea, C. De Stefano, D. Milea, S. Sammartano, Coord. Chem. Rev. 2008, 252, 1108-1120.

http://dx.doi.org/10.1016/j.ccr.2007.09.008

2. E. Graf, J. W. Eaton, Free Radical Biol. Med. 1990, 8,
61-69. http://dx.doi.org/10.1016/0891-5849(90)90146-A

3. I. Vucenik, A. M. Shamsuddin, J. Nutr. 2003, 133, 3778- 3784.

4. M. Strlič, J. Kolar, B. Pihlar, Polym. Degrad. Stab. 2001, 73, 535-539. http://dx.doi.org/10.1016/S0141-3910(01)00120-3

5. Y. H. Wang, J. B. He, Electrochim. Acta 2012, 66, 45-51. http://dx.doi.org/10.1016/j.electacta.2012.01.063

6. D. Peca, B. Pihlar, I. Milosev, Acta Chim. Slov. 2014, 61, 457-467.

7. Q. J. Xu, Z. Y. Wan, G. D. Zhou, R. H. Yin, W. M. Cao, AntiCorros. Methods Mater. 2009, 56, 95-102. http://dx.doi.org/10.1108/00035590910940087

8. B. L. Turner, M. J. Papházy, P. M. Haygarth, I. D. McKelvie, Philos. Trans. R. Soc. London, Ser. B 2002, 357, 449-469.

9. N. Sasakawa, M. Sharif, M. R. Hanley, Biochem. Pharmacol. 1995, 50, 137-146. http://dx.doi.org/10.1016/0006-2952(95)00059-9

10. V. Kumar, A. K. Sinha, H. P. S. Makkar, K. Becker, Food Chem. 2010, 120, 945-959. http://dx.doi.org/10.1016/j.foodchem.2009.11.052

11. H. W. Lopez, F. Leenhardt, C. Coudray, C. Remesy, Int. J. Food Sci. Technol. 2002, 37, 727-739. http://dx.doi.org/10.1046/j.1365-2621.2002.00618.x

12. C. Brigando, J. C. Mossoyan, F. Favier, D. Benlian, J. Chem. Soc., Dalton Trans. 1995, 575-578. http://dx.doi.org/10.1039/dt9950000575

13. H. Bieth, B. Spiess, J. Chem. Soc., Faraday Trans. 1 1986, 82, 1935-1943. http://dx.doi.org/10.1039/f19868201935

14. N. Li, O. Wahlberg, I. Puigdomenech, L. O. Öhman, Acta Chem. Scand. 1989, 43, 331-339. http://dx.doi.org/10.3891/acta.chem.scand.43-0331

15. A. Bebot-Brigaud, C. Dange, N. Fauconnier, C. Gérard, J. Inorg. Biochem. 1999, 75, 71-78. http://dx.doi.org/10.1016/S0162-0134(99)00041-0

16. C. J. Martin, W. J. Evans, J. Inorg. Biochem. 1986, 27, 17-30. http://dx.doi.org/10.1016/0162-0134(86)80105-2

17. P. Crea, A. de Robertis, C. de Stefano, S. Sammartano, Biophys. Chem. 2006, 124, 18-26. http://dx.doi.org/10.1016/j.bpc.2006.05.027

18. Z. Szakács, M. Kraszni, B. Noszál, Anal. Bioanal. Chem. 2004, 378, 1428-1448. http://dx.doi.org/10.1007/s00216-003-2390-3

19. J. Torres, N. Veiga, J. S. Gancheff, S. Domínguez, A. Mederos, M. Sundberg, A. Sanchez, J. Castiglioni, A. Díaz, C. Kremer, J. Mol. Struct. 2008, 874, 77-88. http://dx.doi.org/10.1016/j.molstruc.2007.03.035

20. A. E. Martell, R. M. Smith, Critical Stability Constants, Other Organic Ligands, Plenum Press, New York, 1977. http://dx.doi.org/10.1007/978-1-4757-1568-2

21. L. G. Sillén, A. E. Martell, J. Bjerrum, Stability Constants of Metal-Ion Complexes, Chemical Society, London, 1964.

22. P. Gans, A. Sabatini, A. Vacca, Talanta 1996, 43, 1739-1753. http://dx.doi.org/10.1016/0039-9140(96)01958-3

23. L. Alderighi, P. Gans, A. Ienco, D. Peters, A. Sabatini, A. Vacca, Coord. Chem. Rev. 1999, 184, 311-318. http://dx.doi.org/10.1016/S0010-8545(98)00260-4 
24. N. Li, O. Wahlberg, I. Puigdomenech, Chemica Scripta 1989, 29, 91-95.

25. C. De Stefano, D. Milea, S. Sammartano, Thermochim. Acta 2004, 423, 63-69. http://dx.doi.org/10.1016/j.tca.2004.04.017

26. C. De Stefano, D. Milea, A. Pettignano, S. Sammartano, Anal. Bioanal. Chem. 2003, 376, 1030-1040. http://dx.doi.org/10.1007/s00216-003-2056-1

27. D. B. Thompson, J. W. Erdman, Cereal Chem. 1982, 59, 525-528.

28. J. R. Van Wazer, K. A. Holst, J. Am. Chem. Soc. 1950, 72, 639-644. http://dx.doi.org/10.1021/ja01158a001

29. J. R. Van Wazer, D. A. Campanella, J. Am. Chem. Soc. 1950, 72, 655-663. http://dx.doi.org/10.1021/ja01158a004

30. N. Veiga, J. Torres, C. Bazzicalupi, A. Bianchi, C. Kremer, Chem. Commun. 2014, 50, 14971-14974. http://dx.doi.org/10.1039/C4CC07226J

31. N. Veiga, J. Torres, I. Macho, K. Gomez, G. Gonzalez, C. Kremer, Dalton Trans. 2014, 43, 16238-16251. http://dx.doi.org/10.1039/C4DT01350F

32. C. De Stefano, D. Milea, S. Sammartano, J. Chem. Eng. Data 2003, 48, 114-119. http://dx.doi.org/10.1021/je020124m

33. P. Crea, C. De Stefano, D. Milea, N. Porcino, S. Sammartano, Biophys. Chem. 2007, 128, 176-184. http://dx.doi.org/10.1016/j.bpc.2007.04.003

34. C. Bretti, C. De Stefano, G. Lando, S. Sammartano, Thermochim. Acta 2013, 566, 193-202. http://dx.doi.org/10.1016/j.tca.2013.05.044

35. J. Torres, S. Domínguez, M. F. Cerdá, G. Obal, A. Mederos,
R. F. Irvine, A. Díaz, C. Kremer, J. Inorg. Biochem. 2005, 99, 828-840.

http://dx.doi.org/10.1016/j.jinorgbio.2004.12.011

36. H. Persson, M. Türk, M. Nyman, A. S. Sandberg, J. Agric. Food. Chem. 1998, 46, 3194-3200.

http://dx.doi.org/10.1021/jf971055w

37. A. S. Sandberg, R. Ahderinne, J. Food Sci. 1986, 51, 547-550. http://dx.doi.org/10.1111/j.1365-2621.1986.tb13875.x

38. Q. C. Chen, B. W. Li, J. Chromatogr. A 2003, 1018, 41-52. http://dx.doi.org/10.1016/j.chroma.2003.08.040

39. J. A. Maga, J. Agric. Food. Chem. 1982, 30, 1-9. http://dx.doi.org/10.1021/jf00109a001

40. P. T. Hawkins, D. R. Poyner, T. R. Jackson, A. J. Letcher, D. A. Lander, R. F. Irvine, Biochem. J. 1993, 294, 929-934.

41. W. J. Evans, C. J. Martin, J. Inorg. Biochem. 1991, 41, 245252. http://dx.doi.org/10.1016/0162-0134(91)80016-B

42. H. R. Quirrenbach, F. Kanumfre, N. D. Rosso, M. A. Carvalho, Cienc. Tecnol. Aliment. 2009, 29, 24-32. http://dx.doi.org/10.1590/S0101-20612009000100005

43. M. Šala, D. Makuc, J. Kolar, J. Plavec, B. Pihlar, Carbohydr. Res. 2011, 346, 488-494. http://dx.doi.org/10.1016/j.carres.2010.12.021

44. C. Bretti, R. M. Cigala, G. Lando, D. Milea, S. Sammartano, J. Agric. Food. Chem. 2012, 60, 8075-8082. http://dx.doi.org/10.1021/jf302007v

45. W. J. Evans, A. G. Pierce, J. Food Sci. 1982, 47, 1014-1015. http://dx.doi.org/10.1111/j.1365-2621.1982.tb12769.x

46. G. Mali, M. Šala, I. Arčon, V. Kaučič, J. Kolar, J. Phys. Chem. B 2006, 110, 23060-23067.

http://dx.doi.org/10.1021/jp0633805

\section{Povzetek}

Pri določevanju ravnotežnih konstant protonacije in/ali konstant stabilnosti kovinskih kompleksov s fitati je ključnega pomena standardizacija, oziroma pravilna določitev množine (koncentracije) fitinske kisline. V tem delu je predstavljen nov pristop za precizno in zanesljivo določevanje fitinske kisline s potenciometrično titracijo, ki temelji na izračunu razlik med ekvivalentnimi točkami. Glede na kislost je dvanajst protonov fitinske kisline razvrščenih v tri glavne skupine, kar nam v odvisnosti od eksperimentalnih pogojev, tj. tipa in koncentracije proti-ionov, omogoča detekcijo dveh do treh izrazito razvidnih ekvivalentnih točk. Poleg pravilne določitve množine fitinske kisline je s pomočjo primerjave razlik med posameznimi ekvivalentnimi točkami možna tudi identifikacija morebitne kontaminacije in/ali napoved prvotne stopnje protonacije fitata. Vpliv negotovosti v poznavanju množine fitinske kisline na izračun konstant protonacije smo ovrednotili s pomočjo simulacijskega računalniškega programa Hyperquad2013. S podrobnejšo analizo titracijskih krivulj, posnetih v prisotnosti $\mathrm{Ca}^{2+}$ in $\mathrm{Fe}^{3+}$ ionov, smo napovedali, da se $\mathrm{Ca}^{2+}$ veže na drugo vezavno mesto na fitatnem ligandu kot $\mathrm{Fe}^{3+}$. 